\title{
SMG1 wt Allele
}

National Cancer Institute

\section{Source}

National Cancer Institute. SMG1 wt Allele. NCI Thesaurus. Code C116679.

Human SMG1 wild-type allele is located in the vicinity of 16p12.3 and is approximately

$122 \mathrm{~kb}$ in length. This allele, which encodes serine/threonine-protein kinase SMG1 protein,

plays a role in the mediation of both mRNA nonsense-mediated decay and serine/threonine protein phosphorylation. 